Article

\title{
Comparison of Tab-To-Busbar Ultrasonic Joints for Electric Vehicle Li-Ion Battery Applications
}

\author{
Abhishek Das *(D), Anup Barai, Iain Masters and David Williams \\ WMG, The University of Warwick, Coventry CV4 7AL, UK; A.Barai@warwick.ac.uk (A.B.); \\ I.G.Masters@warwick.ac.uk (I.M.); David.K.Williams@warwick.ac.uk (D.W.) \\ * Correspondence: a.das.1@warwick.ac.uk; Tel.: +44-247-657-3742
}

Received: 26 June 2019; Accepted: 12 September 2019; Published: 14 September 2019

check for updates

\begin{abstract}
Recent uptake in the use of lithium-ion battery packs within electric vehicles has drawn significant attention to the selection of busbar material and corresponding thickness, which are usually based on mechanical, electrical and thermal characteristics of the welded joints, material availability and cost. To determine joint behaviour corresponding to critical-to-quality criteria, this study uses one of the widely used joining technologies, ultrasonic metal welding (UMW), to produce tab-to-busbar joints using copper and aluminium busbars of varying thicknesses. Joints for electrical and thermal characterisation were selected based on the satisfactory mechanical strength determined from the T-peel tests. Electrical contact resistance and corresponding temperature rise at the joints were compared for different tab-to-busbar joints by passing current through the joints. The average resistance or temperature increase from the $0.3 \mathrm{~mm} \mathrm{Al}$ tab was 0.6 times higher than the $0.3 \mathrm{~mm}$ $\mathrm{Cu}[\mathrm{Ni}] \mathrm{tab}$, irrespective of busbar selection.
\end{abstract}

Keywords: electric vehicle; thin metal film; ultrasonic metal welding; electrical resistance; temperature rise

\section{Introduction}

Lithium-ion (Li-ion) electrochemistry-based secondary batteries are now widely used for electrification of automotive vehicles due to several advantages, including high energy density, low self-discharge and portability [1,2]. Greenhouse gases emission legislation has driven the automotive industry to develop fully electric vehicles (EV), hybrid or plug-in hybrid electric vehicles (HEV/PHEV) with low carbon emissions [3,4]. To assist in meeting emission legislation, automotive manufacturers are moving towards lightweight applications, intelligent automation or adapting new powertrain technology based on hybrid or pure secondary batteries. Furthermore, Li-ion batteries are progressively being used for large-scale energy storage systems for grid applications [5]. As a consequence, there is substantial demand for battery manufacturing which involves a large number of individual cells to be connected either in series or parallel to deliver the required power and driving range [6]. For example, the widely used pouch cell format uses a tab-to-busbar connection as the electrical interconnect. Based on the module design, a number of pouch cells are to be connected within a module and several modules are arranged in a battery pack or storage unit. Therefore, a large number of tab-to-busbar joints are inevitable, and each must provide electrically and thermally suitable connections in which vehicles are often exposed to harsh driving conditions [7]. The busbar plays an important role in providing desired electrical and thermal characteristics combined with mechanical strengths. In general, the selection of busbar material and its thickness are largely based on the current carrying capacity, mechanical and electrical characteristics and cost [8]. In addition, busbar material and thickness play a vital role in avoiding excessive heat generation at the tab-to-busbar interconnects. Copper and aluminium are the widely used as busbar materials across the electrical, power, electronic 
or automotive industries [9-11]. Traditionally, copper has been used for busbars due to its excellent mechanical and electrical properties. However, more recently aluminium has been used especially for lightweight applications. Lewchalermwong et al. [12] conducted a study on selection of busbar material based on electrical resistance and thermal expansion of both copper and aluminium busbars. However, extensive study considering the tab-to-busbar joints needs upmost research attention to avoid excessive resistance or heat generation at the tab-to-busbar interconnects.

One of the widely accepted joining methods to connect the pouch cell tab to the busbar is ultrasonic metal welding (UMW) due to several advantages, including joining of dissimilar materials of varying thickness, joining of highly reflective and conductive material, multiple stack-ups and low thermal input during the welding [6,13]. Li-ion battery packs for General Motors' (GM) Chevy Volt and the Nissan LEAF are currently being manufactured using UMW where the pouch cell tabs are connected with busbars [6,14]. Research has been conducted on understanding the ultrasonic metal welding joining mechanism [15-18], microstructure and material properties [19-21], thin to thick material joining (i.e., varying stack-ups) [22], process robustness and optimisation [13,23,24], and mechanical and vibrational behaviours of the welded joints $[25,26]$, which are reported in the literature. In spite of UMW's extensive use and wide research, there are a few critical areas which are yet to be addressed, including electrical resistance and thermal behaviour of the joint.

Little research can be found in the area of busbar-to-busbar connections. Published work mainly considers the mechanical joints, such as nuts and bolts [27,28], focuses on evaluation of contact resistance at varying contact pressure, and even identifies the effect of coating materials on the busbar [10]. However, UMW joint-based electrical and thermal characterisation is missing from the literature. An attempt has been made by Brand et al. [29] to measure the electrical resistance at the UMW joint and they observed that maximum tensile load corresponded to lower electrical resistance when ultrasonic welding was employed to join two brass (CuZn37) test samples. Additionally, Das et al. [30] reported the electrical resistance change and temperature rise at battery tab joints between the $\mathrm{Al} / \mathrm{Cu}[\mathrm{Ni}]$ tab to single $\mathrm{Cu}$ busbar assembly. However, extensive electrical and thermal characterisation of ultrasonic welded joints considering different busbar materials with varying thicknesses are missing from the literature. Combining the ultrasonic welded joints and busbar variation, limited work has been reported so far to characterise their critical-to-quality behaviours, including mechanical strength, electrical resistance and temperature rise at the joint. Therefore, this study focuses on tab-to-busbar ultrasonic welded joints to characterise their critical-to-quality behaviour.

The remainder of this paper is arranged as follows: Section 2 provides the details of experimental investigation including materials, ultrasonic welded joint preparation, and set-ups for mechanical, electrical and thermal characterisation; the results and discussions are made in Section 3; and conclusions are drawn in Section 4.

\section{Experimental Details}

The experimental plan was developed based on the joining requirements for different busbar thicknesses. Material selection, ultrasonic metal welded sample preparation, test set-ups for mechanical strength, electrical resistance and thermal characterisation are described in this section.

\subsection{Tab and Busbar Materials}

Typically, a pouch cell consists of two terminal tabs that protrude through seals to allow external connection [31]. In general, nickel-coated copper $(\mathrm{Cu}[\mathrm{Ni}])$ and aluminium $(\mathrm{Al})$ are widely accepted tab materials for pouch cells and act as the negative and positive terminals, respectively. In this study, $0.3 \mathrm{~mm} \mathrm{Cu}[\mathrm{Ni}]$ and $\mathrm{Al}$ tabs were used for the experimental investigations. The selection of bus bar material and corresponding thickness depends on module capacity, thermal management and current carrying capacity. Copper and aluminium are the most commonly used materials for busbar applications in electrical equipment [9] and their general properties at $20^{\circ} \mathrm{C}$ based on the International Annealed Copper Standard (IACS) are listed in Table 1. Although copper is better in 
terms of electrical resistivity, tensile strength and thermal conductivity, Pryor et al. [9] argued that due to higher density of copper, when weight is taken into consideration, aluminium has a conductivity that is approximately 1.85 times that of copper. As a consequence, for applications where weight is a concern (e.g., automotive electric vehicle applications), aluminium may be the better choice. Copper may be the better alternative when size and space are important. However, a comparative study of different busbar materials/thicknesses considering mechanical strength, electrical resistance and thermal behaviour of joints using ultrasonic metal welding is missing from the literature.

Table 1. A comparison of copper and aluminium properties [9,32]. IACS: International Annealed Copper Standard.

\begin{tabular}{ccc}
\hline Properties & Copper $(\mathbf{C u})$ & Aluminium (Al) \\
\hline Electrical resistance $(\mathrm{n} \Omega \mathrm{mm})$ & 17.2 & 28.3 \\
Cross section for same conductivity (\% IACS) & 100 & 156 \\
Weight for same conductivity $(\%$ IACS) & 100 & 54 \\
Thermal conductivity $(\mathrm{W} /(\mathrm{m} \cdot \mathrm{K}))$ & 397 & 230 \\
Temperature coefficient of resistivity $\left(\mathrm{per}^{\circ} \mathrm{K}\right)$ & 0.0039 & 0.004 \\
Density $\left(\mathrm{g} / \mathrm{cm}^{3}\right)$ & 8.91 & 2.7 \\
Tensile strength $\left(\mathrm{N} / \mathrm{mm}^{2}\right)$ & $200-250$ & $50-60$ \\
\hline
\end{tabular}

The main objectives of this study were to conduct a comparative study between aluminium and copper busbars when they are used for pouch-cell-based battery pack manufacture. Joint behaviour is characterised in terms of mechanical strength, electrical resistance and temperature rise. To identify the joint characteristics, $\mathrm{Cu}$ and $\mathrm{Al}$ busbar materials were chosen with varying thicknesses. The details of tab and busbar materials, their specifications and corresponding thicknesses are listed in Table 2 . In general, the Ni-coated copper is commonly used as tabs, and nickel coating of approximately $2 \mu \mathrm{m}$ was used for this experimental investigation. The copper tabs are generally connected with cell electrodes and Ni coating is mainly used for corrosion resistance, whereas the copper busbar is externally connected to the tabs. Both busbar and tab sample coupon dimensions were $100 \mathrm{~mm}$ in length by $25 \mathrm{~mm}$ in width [21], as shown in Figure $1 \mathrm{~b}$.

Table 2. Tab and busbar materials used for experimental investigations.

\begin{tabular}{|c|c|c|c|}
\hline \multicolumn{4}{|c|}{ Material Details } \\
\hline Type & Material & Specification & Thickness [mm] \\
\hline \multirow{2}{*}{ Upper material-Tabs } & Aluminium $(\mathrm{Al})$ & AW1050A-H18; BS EN546 & 0.3 \\
\hline & Ni-coated Copper $(\mathrm{Cu}[\mathrm{Ni}])$ & CW004A-H040; BS EN1652 (C101Sl) & 0.3 \\
\hline \multirow{2}{*}{ Lower material-Busbar } & Aluminium (Al) & AW1050A-H14; BS EN485 & $1.0,1.5,2.0,2.5$ \\
\hline & Copper $(\mathrm{Cu})$ & CW004A-H065; BS EN1652 (C101HH) & $1.0,1.5,2.0$ \\
\hline
\end{tabular}
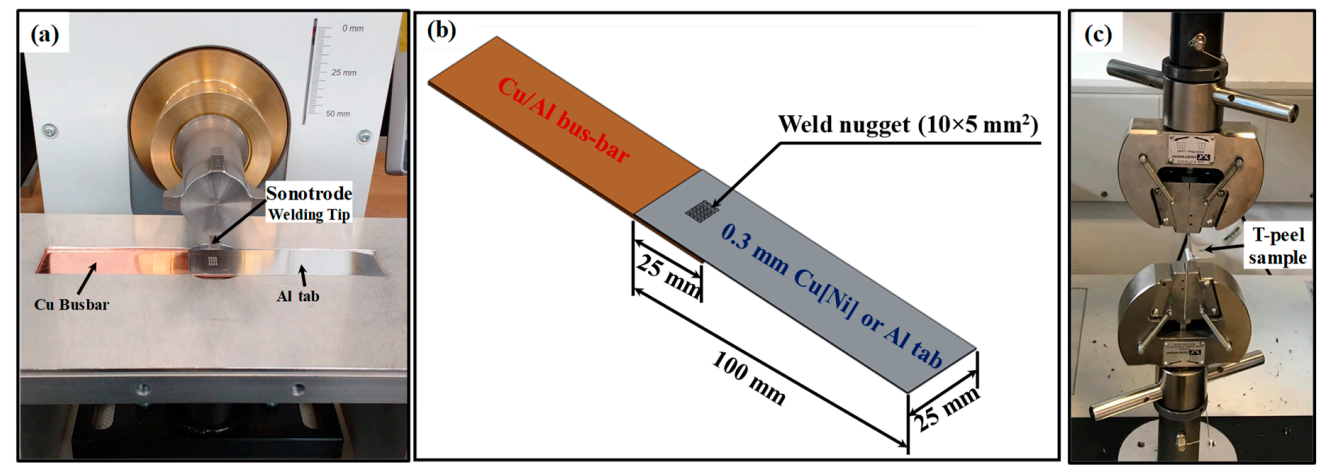

Figure 1. (a) Ultrasonic metal welding joining set-up; (b) a pictorial example of ultrasonic welding to produce tab-to-busbar interconnect in lap configuration; and (c) T-peel test set-up for mechanical strength characterisation. 


\subsection{Tab-To-Busbar Joints Using Ultrasonic Metal Welding}

As ultrasonic metal welding is most suitable for thin to thick material, the tab was used as the upper part and the busbar as the lower during joining, i.e., the sonotrode oscillation with defined amplitude propagated from the tab to the busbar which was supported by the stationary anvil. Ultrasonic metal welding was performed using a Telsonic MPX ultrasonic welder as shown in Figure 1a operating at $20 \mathrm{kHz}$, having $6.5 \mathrm{~kW}$ maximum power and allowable amplitude variation from 30 to $60 \mu \mathrm{m}$.

Figure $1 \mathrm{~b}$ shows the typical arrangement of placing the ultrasonic weld nugget (i.e., $10 \mathrm{~mm} \times$ $5 \mathrm{~mm}$ ) at the centre of $25 \mathrm{~mm}$ overlap between tab and busbar. This lap configuration was used for both electrical and thermal characterisation. The T-peel test was used to evaluate joint strength with respect to the ultrasonic welding parameters. It can be observed from the literature that researchers have used welding pressure, welding time and amplitude as the most influencing weld parameters to achieve satisfactory weld strength and weld quality $[23,24]$. In this study, $0.3 \mathrm{~mm} \mathrm{Cu}[\mathrm{Ni}]$ and $\mathrm{Al}$ tabs were welded to $1.0 \mathrm{~mm} \mathrm{Cu}$ and $\mathrm{Al}$ busbars, respectively, to identify satisfactory process parameters by varying welding pressure, welding time and amplitude of ultrasonic vibration. The process parameters and corresponding levels are given in Table 3 . The trigger mode time was set at $0.2 \mathrm{~s}$ which allowed converting of the traversing pressure to welding pressure. The welding pressure was varied from 0.5 to 4.0 bar with incremental increases of 0.5 bar while amplitude of vibration and welding time were set at $35 \mu \mathrm{m}$ and $0.25 \mathrm{~s}$, respectively. These parametric values were chosen based on pilot tests. Five levels of amplitude were chosen from 30 to $50 \mu \mathrm{m}$ with increments of $5 \mu \mathrm{m}$ while welding pressure was kept constant at 1.5 bar and welding time at $0.25 \mathrm{~s}$. Similarly, the welding time was increased from 0.15 to $0.55 \mathrm{~s}$ at $0.15 \mathrm{~s}$ intervals when welding pressure and welding amplitude were held at $1.5 \mathrm{bar}$ and 50 $\mu \mathrm{m}$, respectively.

Table 3. Level of process parameters for experimentation.

\begin{tabular}{cc}
\hline Process parameter & Value \\
\hline Welding pressure $(\mathrm{bar})$ & $0.5,1.0,1.5,2.0,2.5,3.0,3.5,4.0$ \\
Welding amplitude $(\mu \mathrm{m})$ & $30,35,40,45,50$ \\
Welding time $(\mathrm{s})$ & $0.15,0.25,0.35,0.45,0.55$ \\
\hline
\end{tabular}

\subsection{Set-Up for Mechanical Strength Characterisation}

The output variable chosen to represent the weld quality was the maximum load obtained from the T-peel tests. These T-peel tests were performed to evaluate the effects of welding process parameters on the joint strength. The test set-up for the T-peel test is shown in Figure 1c where the samples (i.e., open end of tab and busbar) were bent by $90^{\circ}$ in opposite directions allowing them to be held by a lower static grip and upper moving grip. Using an Instron 3367 static test frame with $30 \mathrm{kN}$ load cell, a test speed of $20 \mathrm{~mm} / \mathrm{min}$ was applied to perform the T-peel tests in order to minimise the unexpected dynamic effect for weld failure [20]. The peak load during the T-peel test was recorded in order to evaluate the mechanical strength of the weld and further used as a measure of weld performance. To obtain preferred process parameters with satisfactory T-peel load, tests were performed using the samples produced as listed in Table 3. Each test variant was repeated three times, and the average of the three replicates was used for analyses. Relying on the load-displacement characteristics, Das et al. [13] defined three weld conditions which were under-weld, good-weld and over-weld. Furthermore, they explained these three categories using weld cross-sectional images where under-weld showed un-bonded gaps between the mating surface, good-weld exhibited uniform bonding along the weld cross-section, and over-weld was excessive thinning with a tab broken zone. This weld classification was used in this study while evaluating the weld quality using T-peel tests. 


\subsection{Set-Up for Electrical and Thermal Characterisation}

In order to evaluate the electrical resistance and temperature rise at the joint, the lap configuration samples, as shown in Figure 1b, were produced using the parameters corresponding to maximum strength in the T-peel test. The schematic representation and test set-up for electrical and thermal characterisation are shown in Figure 2. The sample was mounted in a fixture using brass blocks which were connected to the power supply and voltage sensor. An additional voltage sensor was placed to measure the potential difference across the joint when current was applied. The resistance was calculated using the induced voltage due to the application of current. As a result of resistive heat loss, the weld area heated up and the corresponding temperature rise was measured using a thermal camera placed directly above the weld location. A FLIR T440 thermal camera was employed to record the joint temperature during the current application. It has been reported that $\mathrm{Li}$-ion pouch cells are often exposed to aggressive automotive duty cycles, such as a race cycle, which are dominated by a high current application up to $300 \mathrm{amp}[33,34]$. As the purpose of this study was to characterise the joint behaviour based on the busbar thickness, a high value of current, i.e., $250 \mathrm{amp}$, was passed through the joint for $60 \mathrm{~s}$ to visualise the temperature rise. As a result of this current application, the resistance change coupled with temperature rise at the joint area was captured.

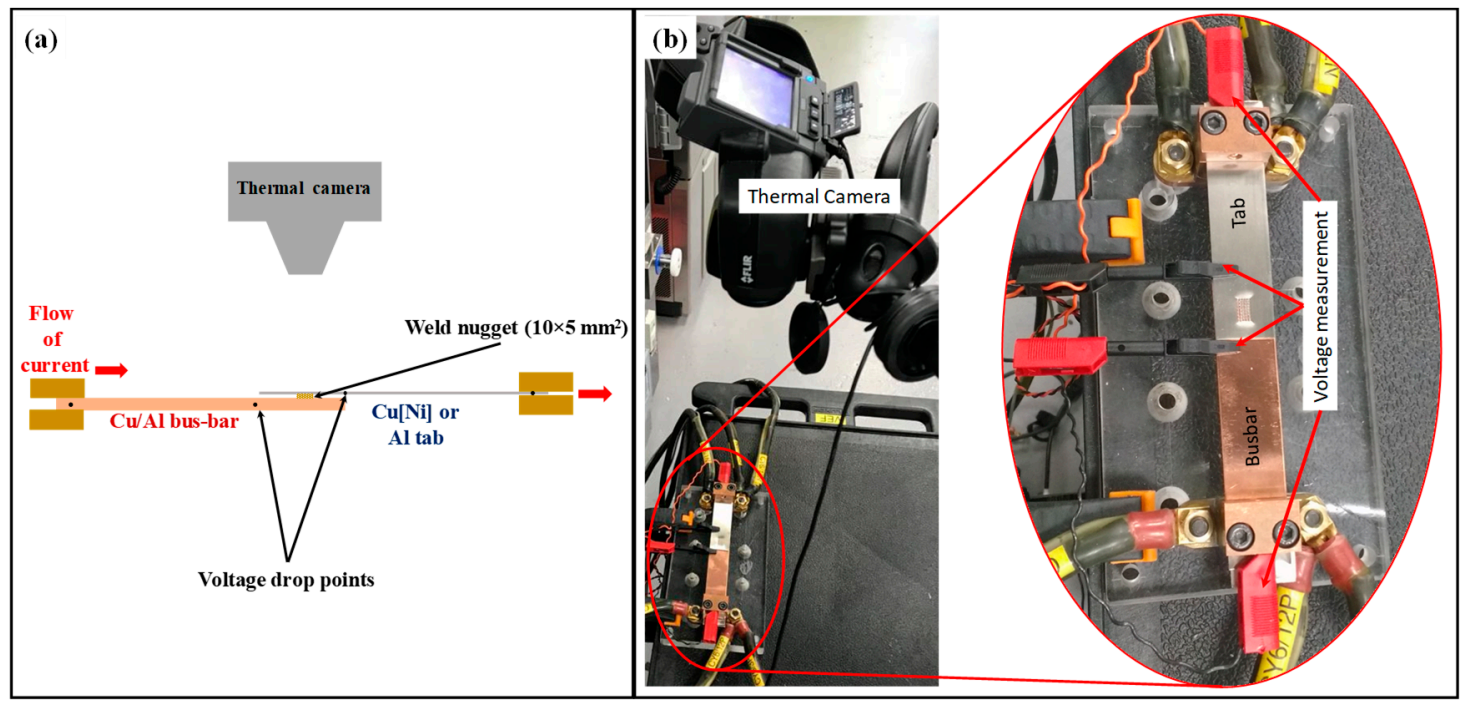

Figure 2. Test set-up for electrical and thermal characterisation of tab-to-busbar joints (a) schematic view; and (b) experimental set-up.

\section{Results and Discussion}

\subsection{Joint Strength Behaviour}

In order to obtain the satisfactory ultrasonic welding process parameters for $0.3 \mathrm{~mm} \mathrm{Cu}[\mathrm{Ni}]$ and Al tabs for different busbar materials and thicknesses, as shown in Table 2, the mechanical strength of the weld was evaluated by performing T-peel tests. Initially, $0.3 \mathrm{~mm} \mathrm{Al}$ tabs with a $1.0 \mathrm{~mm} \mathrm{Al}$ busbar and a $0.3 \mathrm{~mm} \mathrm{Cu}[\mathrm{Ni}]$ tab with a $1.0 \mathrm{~mm} \mathrm{Cu}$ busbar were considered for process parameter selection. The maximum T-peel loads under varying welding pressure for both the $0.3 \mathrm{~mm} \mathrm{Al}$ tab to $1.0 \mathrm{~mm} \mathrm{Al}$ busbar and the $0.3 \mathrm{~mm} \mathrm{Cu}[\mathrm{Ni}]$ tab to $1.0 \mathrm{~mm} \mathrm{Cu}$ busbar are plotted in Figure $3 \mathrm{a}$. In the case of $0.3 \mathrm{~mm} \mathrm{Al}$ tab to $1.0 \mathrm{~mm} \mathrm{Al}$ busbar joints, the T-peel strength was above $200 \mathrm{~N}$ in between 1 and 3.5 bar. However, beyond 2.5 bar the joints showed excessive $\mathrm{Al}$ tab deformation and were not recommended for further evaluation. The highest T-peel load and acceptable top surface deformation were obtained at 1.5 bar welding pressure. Similarly, for $0.3 \mathrm{~mm} \mathrm{Cu}[\mathrm{Ni}]$ tab to $1.0 \mathrm{~mm} \mathrm{Cu}$ busbar joints, welding pressure of 1.5 bar produced the highest T-peel strength. Therefore, for both the $0.3 \mathrm{~mm} \mathrm{Al}$ tab

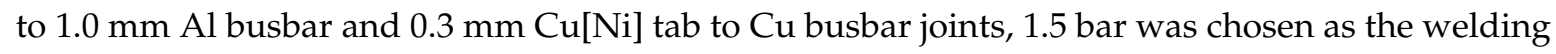


pressure when varying busbar thicknesses were used. The effect of amplitude on T-peel strength for both the joint configurations are plotted in Figure 3b. In general, under-welds were produced at low value of amplitudes (e.g., at 30/35 $\mu \mathrm{m}$ ) and gradually shifted towards good-welds as amplitude increased [13]. For both configurations, an amplitude of $50 \mu \mathrm{m}$ produced joints with the highest T-peel strength and was selected for electrical and thermal characterisation. A steady increase in T-peel load was observed with increasing welding time, as shown in Figure 3c, especially for the $0.3 \mathrm{~mm} \mathrm{Cu}[\mathrm{Ni}]$ tab to $1.0 \mathrm{~mm} \mathrm{Cu}$ busbar joint, where a $0.55 \mathrm{~s}$ welding time resulted in the highest average T-peel load of $261 \mathrm{~N}$. In contrast, T-peel load was slightly reduced for $0.3 \mathrm{~mm} \mathrm{Al} \mathrm{tab} \mathrm{to} 1.0 \mathrm{~mm}$ Al busbar joints at $0.55 \mathrm{~s}$ due to excessive deformation and an over-weld condition [13]. As a balance between under-weld and over-weld, a $0.35 \mathrm{~s}$ welding time was preferred for producing joints of $0.3 \mathrm{~mm} \mathrm{Al}$ tabs to varying thicknesses of Al busbars. The preferred welding pressure, welding amplitude and welding time are listed in Figure $3 \mathrm{~d}$ which was used for producing samples for electrical and thermal characterisation.

(a)

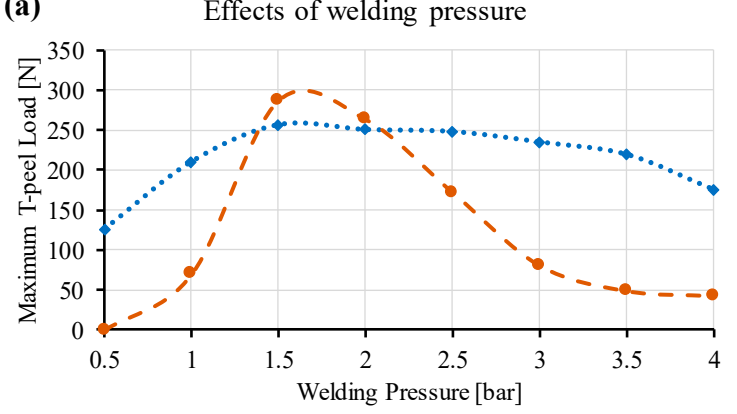

(c)

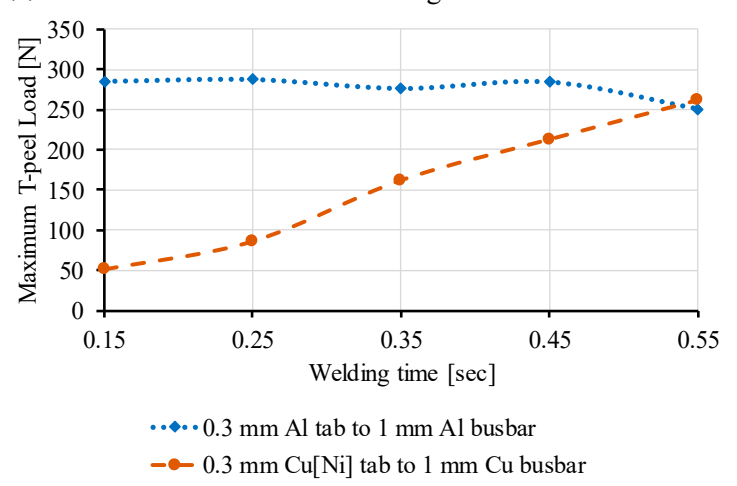

(b)

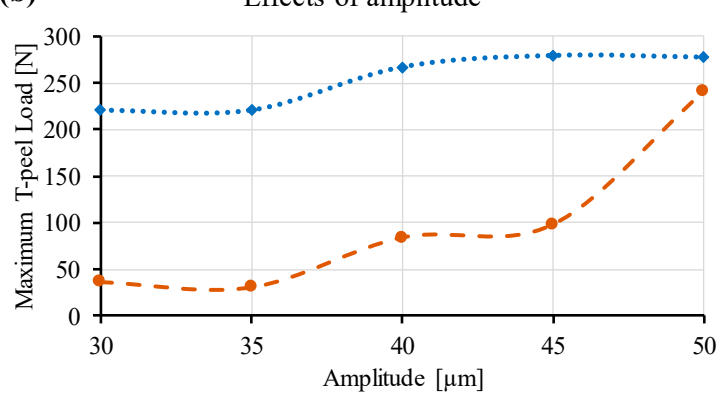

(d)

\begin{tabular}{|l|c|c|}
\hline & $\begin{array}{c}0.3 \mathrm{~mm} \mathrm{Al} \mathrm{tab} \\
\text { to Al Busbar }\end{array}$ & $\begin{array}{c}0.3 \mathrm{~mm} \mathrm{Cu}[\mathrm{Ni}] \\
\text { tab to } \mathrm{Cu} \text { busbar }\end{array}$ \\
\hline $\begin{array}{l}\text { Welding Pressure } \\
\text { (bar) }\end{array}$ & 1.5 & 1.5 \\
\hline $\begin{array}{l}\text { Welding Amplitude } \\
(\mu \mathrm{m})\end{array}$ & 50 & 50 \\
\hline Welding Time $(\mathrm{sec})$ & 0.35 & 0.55 \\
\hline
\end{tabular}

Figure 3. Maximum T-peel load obtained from (a) welding pressure variation; (b) amplitude variation; (c) welding time variation; and (d) parameters selected for producing samples for electrical and thermal characterisation.

\subsection{Joint Electrical Resistance Behaviour}

Due to application of $250 \mathrm{amp}$ current through the joints, the induced voltage across the joints was measured using the voltage sensors as shown in Figure 2. Based on the induced voltage, the electrical resistance was determined at the joint area for two different tab-based configurations, i.e., $0.3 \mathrm{~mm} \mathrm{Al}$ tabs and $0.3 \mathrm{~mm} \mathrm{Cu}[\mathrm{Ni}]$ tabs to different busbars. As current was applied for $60 \mathrm{~s}$, it was observed that the resistance was slowly increasing within the period of current application due to heat generation, although the gradient of the profile depends on the busbar material and corresponding thickness. Figure 4a shows the electrical resistance change of the $0.3 \mathrm{~mm} \mathrm{Al}$ tab to different thicknesses of $\mathrm{Al} / \mathrm{Cu}$ busbar joints due to application of current. Under a uniform flow of electric current, the electrical resistance is expressed as $R=\rho l / A$, where $\rho$ represents the resistivity, $l$ is the length and $A$ is the cross-sectional area [30,35]. Furthermore, Das et al. [30] reported detailed theoretical analysis and simulation methodology for electrical and thermal characterisation based on a single tab-to-busbar joint. 
In this experimental investigation, voltage sensors were placed across the joints, keeping the length of measured length constant. Similarly, identical ultrasonic welding parameters were used to produce uniform joints using different thicknesses of busbars to avoid variation during welding operation. However, the cross-sectional area depends on the thickness of the busbar. As the thickness of the busbar increases, it is expected to reduce the resistance of the measured joint. It is worth noting that the starting resistance gradually decreases with increasing thickness of the busbar due to the fact that the resistance decreases with increasing cross-sectional area as the current value remains constant. For example, the starting resistance values were $0.089,0.087,0.080$ and $0.065 \mathrm{~m} \Omega$ for the $0.3 \mathrm{~mm} \mathrm{Al}$ tab to $1.0,1.5,2.0$ and $2.5 \mathrm{~mm} \mathrm{Al}$ busbars, respectively. Comparatively low change in starting resistance was observed for $\mathrm{Cu}$ busbars, e.g., $0.084,0.083$ and $0.080 \mathrm{~m} \Omega$ were obtained from the $0.3 \mathrm{~mm} \mathrm{Al}$ tab to 1.0, 1.5 and $2.0 \mathrm{~mm} \mathrm{Cu}$ busbars. Accordingly, lower busbar thickness gave higher change in resistance values due to the application of current. For example, a $0.034 \mathrm{~m} \Omega$ resistance increase was obtained for the $0.3 \mathrm{~mm} \mathrm{Al}$ tab to the $1.0 \mathrm{~mm} \mathrm{Al} \mathrm{busbar} \mathrm{joint.} \mathrm{These} \mathrm{resistance} \mathrm{change} \mathrm{values} \mathrm{decreased} \mathrm{with}$ increasing busbar thickness, e.g., $0.024,0.021$ and $0.016 \mathrm{~m} \Omega$ resistance changes were obtained from the $0.3 \mathrm{~mm} \mathrm{Al}$ tab to 1.5, 2.0 and $2.5 \mathrm{~mm} \mathrm{Al}$ busbar joints. Similar behaviour was also observed for the $0.3 \mathrm{~mm} \mathrm{Al}$ tab to varying thicknesses of $\mathrm{Cu}$ busbar joints. The percentage change in resistance values for varying thicknesses of $\mathrm{Al}$ and $\mathrm{Cu}$ busbars are shown in Figure $4 \mathrm{~b}$. It is worth noting that similar changes in resistance value were obtained from the $2.0 \mathrm{~mm} \mathrm{Al}$ busbar (i.e., $26.30 \%$ ) and the $1.5 \mathrm{~mm} \mathrm{Cu}$ busbar (i.e., 26.92\%) or the $2.5 \mathrm{~mm} \mathrm{Al} \mathrm{busbar} \mathrm{(i.e.,} \mathrm{24.33 \% )} \mathrm{and} 2.0 \mathrm{~mm} \mathrm{Cu}$ busbar (i.e., 23.54\%) joints.

(a) $0.3 \mathrm{~mm}$ Al tab to varying $\mathrm{Al} / \mathrm{Cu}$ busbars

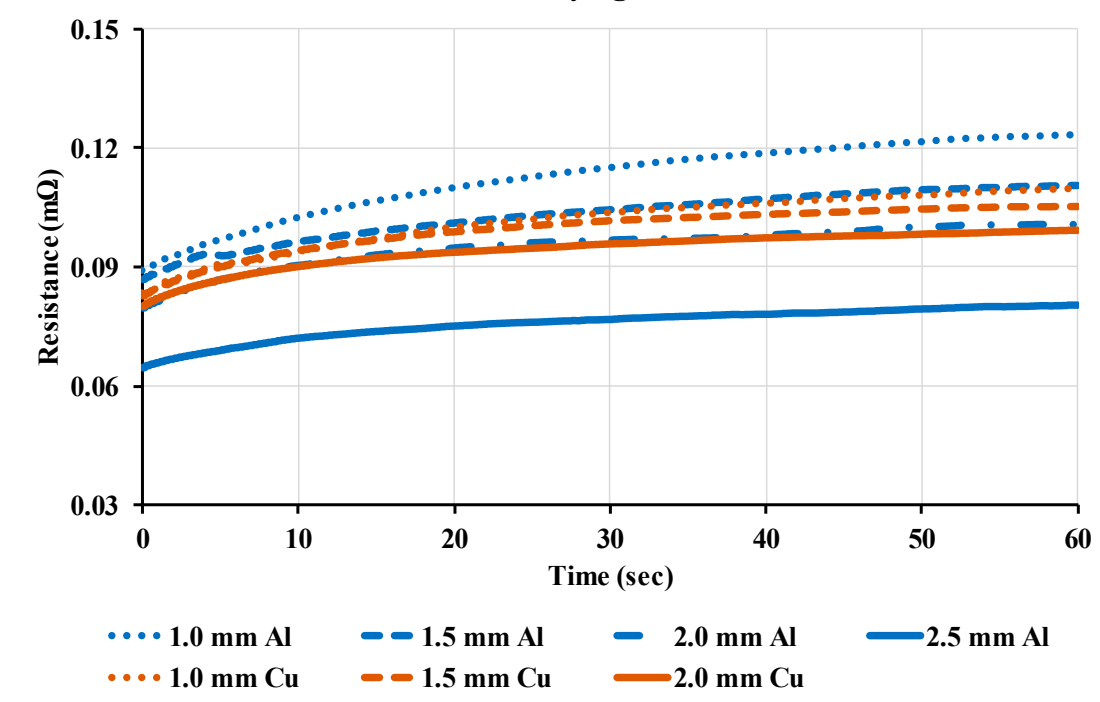

(b)

\section{Change in resistance}

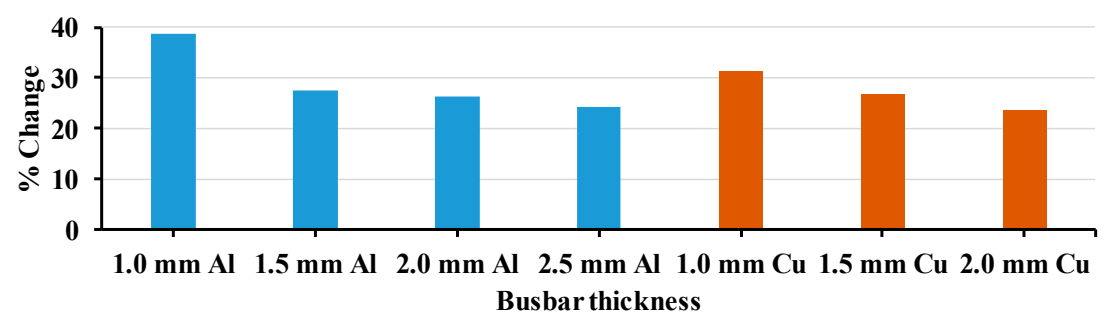

Figure 4. (a) Electrical resistance profiles for $0.3 \mathrm{~mm} \mathrm{Al}$ tab to $\mathrm{Al} / \mathrm{Cu}$ busbars; and (b) the percentage (\%) changes in resistance.

Similarly, joints of the $0.3 \mathrm{~mm} \mathrm{Cu}[\mathrm{Ni}]$ tab to varying thicknesses of $\mathrm{Al} / \mathrm{Cu}$ busbars have incremental change in electrical resistance due to the application of current which are shown in Figure 5. In the case of $0.3 \mathrm{~mm} \mathrm{Cu}[\mathrm{Ni}]$ tab-to-busbar joints, it was observed that electrical resistance at the start of the 
current application was almost the same for joints having a busbar thickness of (i) $1.5 \mathrm{~mm} \mathrm{Al}$ and $1.0 \mathrm{~mm} \mathrm{Cu}$ (i.e., $0.057 \mathrm{~m} \Omega$ ), (ii) $2.0 \mathrm{~mm} \mathrm{Al}$ and $1.5 \mathrm{~mm} \mathrm{Cu}$ (i.e., $0.050 \mathrm{~m} \Omega$ ) and (iii) $2.5 \mathrm{~mm} \mathrm{Al}$ and $2.0 \mathrm{~mm} \mathrm{Cu}$ (i.e., $0.046 \mathrm{~m} \Omega$ ). Furthermore, it is evident from Figure $5 \mathrm{a}$ that the gradient of resistance change decreases with the increasing thickness of the busbar, and with higher thicknesses of busbar, the electrical resistance change profile exhibited a plateau. In line with starting resistance, the range of resistance increase (i.e., the difference in resistance values at the end and start of current application) gradually decreased with increase of busbar thickness for the same materials. For example, maximum incremental increase of $0.013 \mathrm{~m} \Omega$ was obtained for the $0.3 \mathrm{~mm} \mathrm{Cu}[\mathrm{Ni}]$ tab to $1.0 \mathrm{~mm}$ Al busbar joint, and thereafter, the range of resistance increase was gradually decreased to $0.010,0.006$ and $0.005 \mathrm{~m} \Omega$ for 1.5, 2.0 and $2.5 \mathrm{~mm} \mathrm{Al} \mathrm{busbars,} \mathrm{respectively.} \mathrm{In} \mathrm{the} \mathrm{case} \mathrm{of} 0.3 \mathrm{~mm} \mathrm{Cu}[\mathrm{Ni}]$ tab to varying $\mathrm{Cu}$ busbar joints, ranges of resistance increase were $0.0089,0.0053$ and $0.0049 \mathrm{~m} \Omega$ for $1.0,1.5$ and $2.0 \mathrm{~mm} \mathrm{Cu}$ busbars, respectively. The percentage changes in resistance for a $0.3 \mathrm{~mm} \mathrm{Cu}[\mathrm{Ni}]$ tab to varying busbars are shown in Figure $5 \mathrm{~b}$. A maximum of $20.52 \%$ increase in electrical resistance was obtained from the $0.3 \mathrm{~mm} \mathrm{Cu}[\mathrm{Ni}]$ tab to $1.0 \mathrm{~mm} \mathrm{Al}$ busbar joint and lower values were obtained from $2.5 \mathrm{~mm} \mathrm{Al}$ busbars or $2.0 \mathrm{~mm} \mathrm{Cu}$ busbars. The maximum absolute values of electrical resistance obtained at the end of current application from all the tab and busbar combinations are tabulated in Table 4 . It can be observed that an average electrical resistance obtained from a $0.3 \mathrm{~mm} \mathrm{Cu}[\mathrm{Ni}]$ tab is 0.6 times lower than a $0.3 \mathrm{~mm} \mathrm{Al} \mathrm{tab,} \mathrm{irrespective} \mathrm{of} \mathrm{busbar} \mathrm{selection.}$

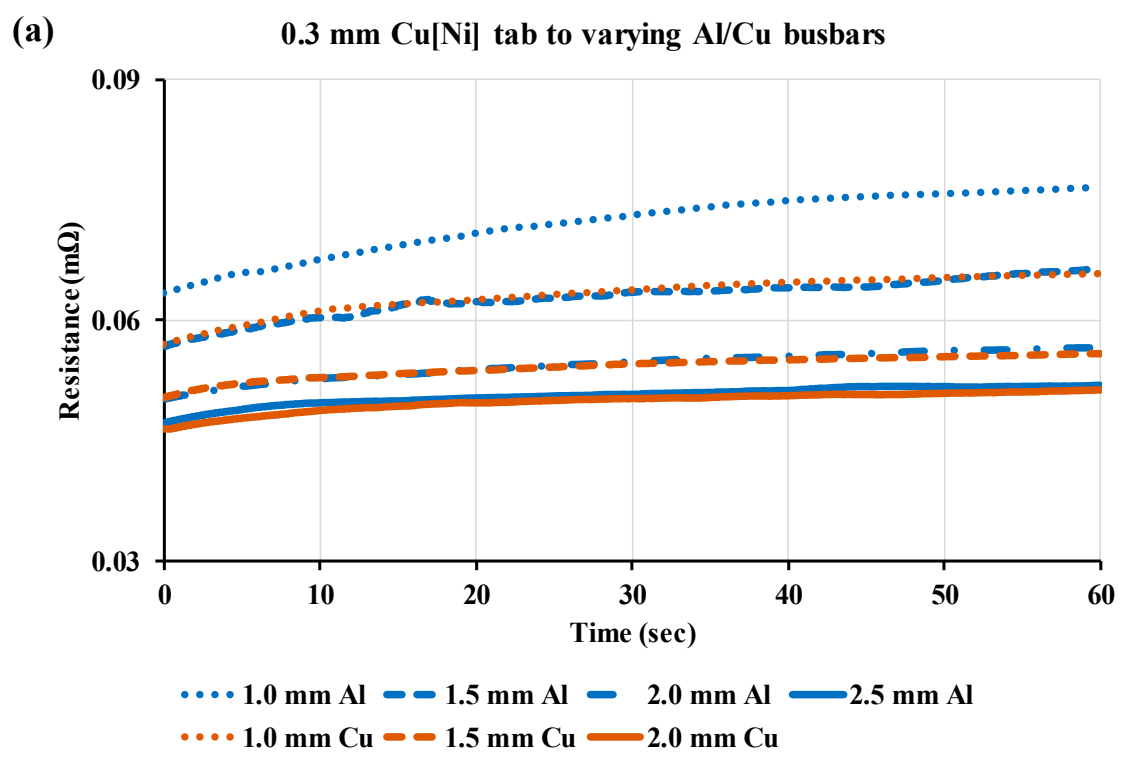

(b) Change in resistance values

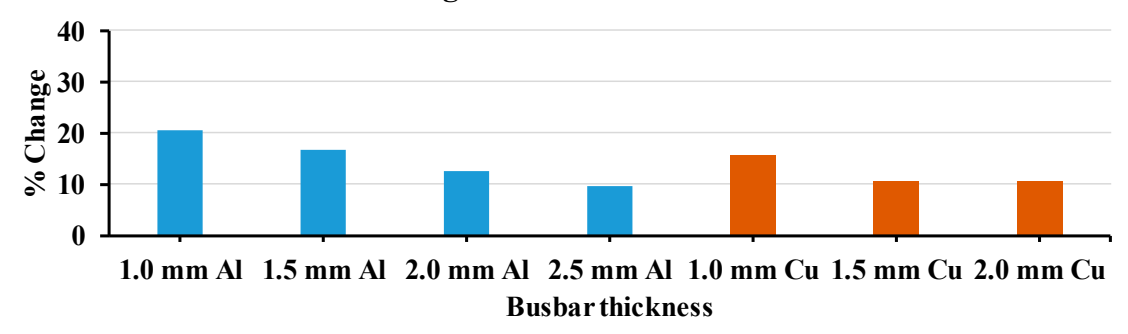

Figure 5. (a) Electrical resistance profiles for $0.3 \mathrm{~mm} \mathrm{Cu}[\mathrm{Ni}]$ tab to $\mathrm{Al} / \mathrm{Cu}$ busbars; and (b) the percentage (\%) changes in resistance. 
Table 4. The maximum values of electrical resistance obtained from all tab and busbar combinations.

\begin{tabular}{cccccccc}
\hline \multirow{2}{*}{ Tab Material } & \multicolumn{4}{c}{ Al Busbar } & \multicolumn{3}{c}{ Cu Busbar } \\
\cline { 2 - 8 } & $\mathbf{1 . 0} \mathbf{~} \mathbf{m}$ & $\mathbf{1 . 5} \mathbf{~} \mathbf{m}$ & $\mathbf{2 . 0} \mathbf{~} \mathbf{m}$ & $\mathbf{2 . 5} \mathbf{~} \mathbf{m}$ & $\mathbf{1 . 0} \mathbf{~ m m}$ & $\mathbf{1 . 5} \mathbf{~} \mathbf{m}$ & $\mathbf{2 . 0} \mathbf{~ m m}$ \\
\hline $0.3 \mathbf{~ m m ~ A l ~ T a b}$ & 0.124 & 0.111 & 0.101 & 0.080 & 0.110 & 0.105 & 0.099 \\
$0.3 \mathbf{~ m m ~ C u}[\mathrm{Ni}] \mathrm{Tab}$ & 0.076 & 0.066 & 0.057 & 0.052 & 0.066 & 0.056 & 0.051 \\
\hline
\end{tabular}

\subsection{Joint Thermal Behaviour}

Li-ion battery degradation is one of the biggest challenges in electric vehicle industries, and one of the main causes for battery aging/degradation is elevated temperature [36]. Hunt et al. [37] argued that tab temperature rise is more alarming than battery surface temperature rise, and they concluded that tab joint cooling rather than surface cooling would be equivalent to extending the lifetime of a pack by 3 times or reducing the lifetime cost by $66 \%$. The temperature profiles of tab-to-busbar joints are reported in Figure 6. All the tests were performed with the same initial start temperature of $25^{\circ} \mathrm{C}$ and the maximum temperature obtained at the end of the tests were different, which was due to the combination of tab and busbar materials along with their associated thicknesses.

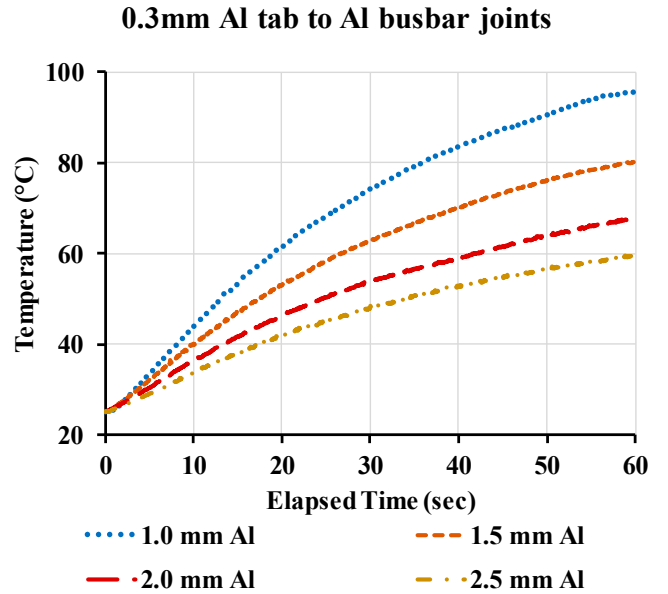

(a)

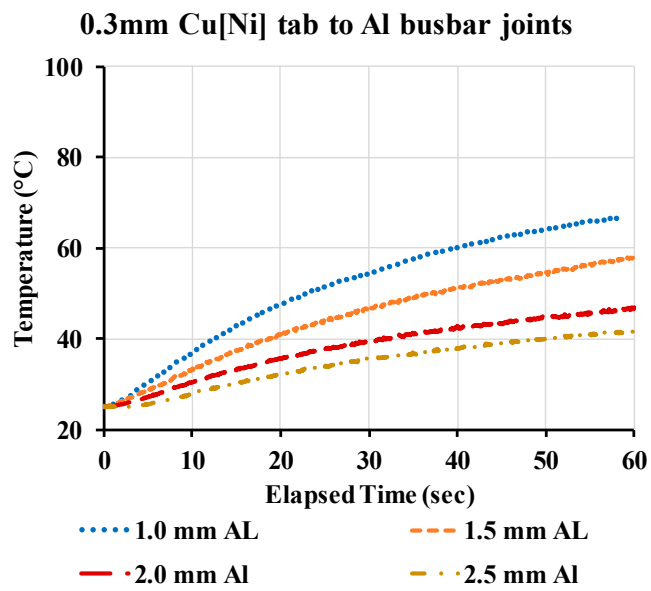

(c)

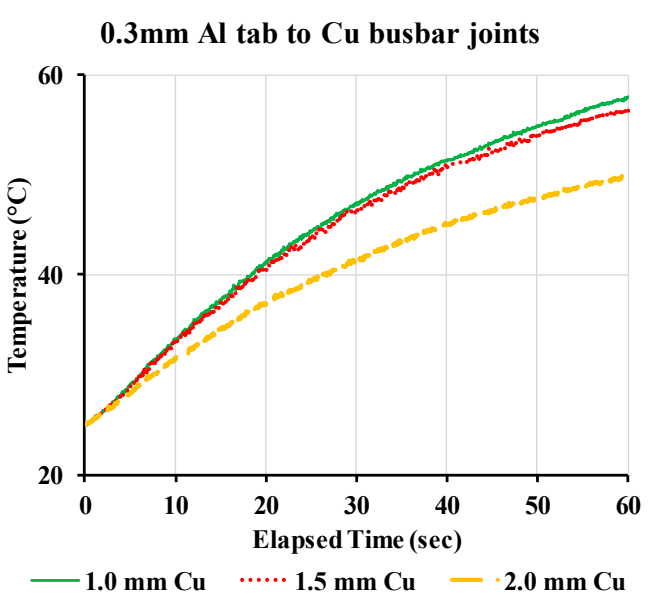

(b)

0.3mm $\mathrm{Cu}[\mathrm{Ni}]$ tab to $\mathrm{Cu}$ busbar joints

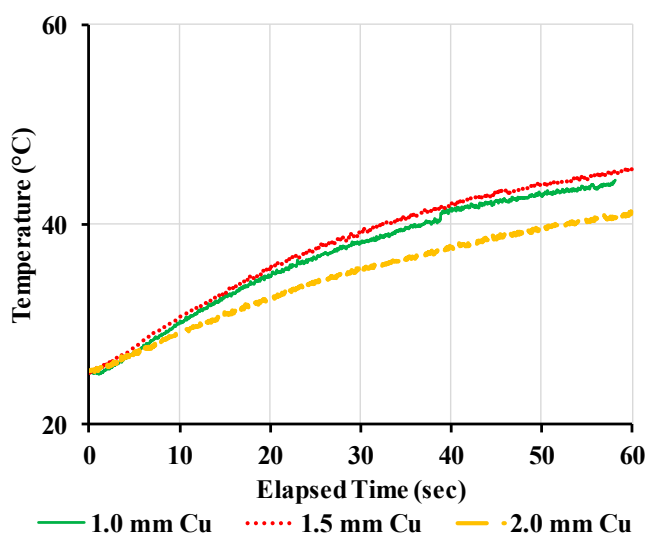

(d)

Figure 6. The temperature rise profiles due to application of $250 \mathrm{amp}$ current for $60 \mathrm{~s}$ through (a) a $0.3 \mathrm{~mm} \mathrm{Al}$ tab to different $\mathrm{Al}$ busbar joints; (b) a $0.3 \mathrm{~mm} \mathrm{Al}$ tab to different $\mathrm{Cu}$ busbar joints; (c) a $0.3 \mathrm{~mm}$ $\mathrm{Cu}[\mathrm{Ni}]$ tab to different $\mathrm{Cu}$ busbar joints; and (d) a $0.3 \mathrm{~mm} \mathrm{Cu}[\mathrm{Ni}]$ tab to different $\mathrm{Cu}$ busbar joints. 
Similar to the change in electrical resistance, the temperature at the joint increases due to heat generation and subsequent electrical resistance change. For example, the highest temperature of $96.18^{\circ} \mathrm{C}$ was measured when a $250 \mathrm{amp}$ current was passed through the $0.3 \mathrm{~mm} \mathrm{Al}$ tab to $1.0 \mathrm{~mm}$ $\mathrm{Al}$ busbar joint for $60 \mathrm{~s}$. With an increase in busbar thickness, the maximum temperature measured at the joint reduced due to a number of reasons, including initial resistance, thermal conductivity, thermal mass and electrical resistance change. For example, maximum temperatures obtained for the $0.3 \mathrm{~mm} \mathrm{Al}$ tab to $1.5,2.0$ and $2.5 \mathrm{~mm} \mathrm{Al}$ busbar joints were $80.27,67.83$ and $59.97^{\circ} \mathrm{C}$, respectively. In general, copper busbar-based joints were not heated as much as Al busbar-based joints due to higher thermal conductivity and lower resistance change. For instance, the temperature rise at the $0.3 \mathrm{~mm} \mathrm{Al}$ tab to $2.0 \mathrm{~mm} \mathrm{Al} \mathrm{busbar} \mathrm{joint} \mathrm{was} 67.83^{\circ} \mathrm{C}$, which is considerably higher than the temperature rise at the $0.3 \mathrm{~mm} \mathrm{Al} \mathrm{tab}$ to $2.0 \mathrm{~mm} \mathrm{Cu}$ busbar joint (i.e., $50.07^{\circ} \mathrm{C}$ ). Figure $6 \mathrm{a}, \mathrm{b}$ shows the temperature responses for the $0.3 \mathrm{~mm} \mathrm{Al}$ tab to varying thicknesses of $\mathrm{Al}$ and $\mathrm{Cu}$ busbar joints, respectively. The maximum temperature obtained from the $2.5 \mathrm{~mm} \mathrm{Al}$ busbar joint (i.e., $59.97^{\circ} \mathrm{C}$ ) is higher than the measured temperature from any of the $\mathrm{Cu}$ busbar joints. Therefore, the performance of copper busbar was better when $\mathrm{Al}$ was used as tabs. The performance of $0.3 \mathrm{~mm} \mathrm{Cu}[\mathrm{Ni}]$ tab to $\mathrm{Al}$ and $\mathrm{Cu}$ busbar joints are plotted in Figure $6 \mathrm{c}, \mathrm{d}$, respectively. As copper is electrically and thermally a better conductor than $\mathrm{Al}$, the temperature rise was lower for $\mathrm{Cu}[\mathrm{Ni}]$ tab-to-busbar joints. For example, the maximum temperature measured for the $0.3 \mathrm{~mm} \mathrm{Cu}[\mathrm{Ni}]$ tab to $1.0 \mathrm{~mm} \mathrm{Al} \mathrm{busbar} \mathrm{joint} \mathrm{was} 66.96^{\circ} \mathrm{C}$, which was significantly lower than the temperature obtained from the $0.3 \mathrm{~mm} \mathrm{Al}$ tab to $1.0 \mathrm{~mm}$ Al busbar joint (i.e., $96.18^{\circ} \mathrm{C}$ ). A comparative percentage (\%) change in temperature values obtained from $0.3 \mathrm{~mm}$ $\mathrm{Al}$ and $\mathrm{Cu}[\mathrm{Ni}]$ tab-to-busbar joints are given in Figure 7. Similar to electrical resistance responses, the average temperature increase from the $0.3 \mathrm{~mm} \mathrm{Al}$ tab was 0.6 times higher than the $0.3 \mathrm{~mm} \mathrm{Cu}[\mathrm{Ni}]$ $\mathrm{tab}$, irrespective of busbar selection.

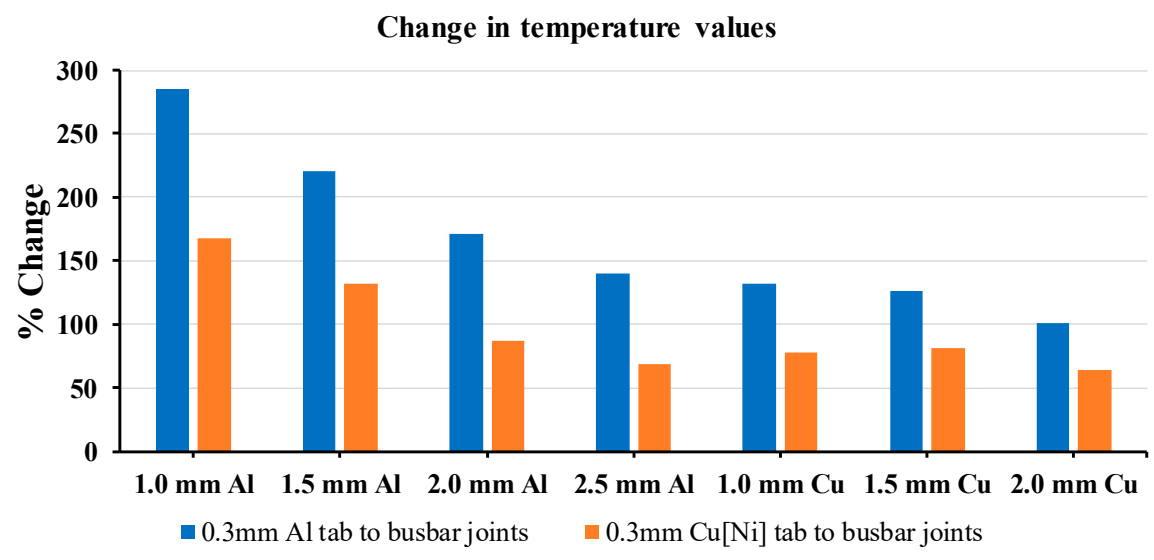

Figure 7. The percentage (\%) changes in temperature due to application of $250 \mathrm{amp}$ current for $60 \mathrm{~s}$ through different tab-to-busbar assemblies.

\section{Conclusions}

This study compared the mechanical strength, electrical resistance and thermal behaviours of tab-to-busbar joints. The critical-to-quality criteria joint criteria, i.e., mechanical strength, electrical resistance and temperature rise were evaluated for $0.3 \mathrm{~mm} \mathrm{Al}$ and $\mathrm{Cu}[\mathrm{Ni}]$ tabs to varying thicknesses of $\mathrm{Al}$ and $\mathrm{Cu}$ busbar joints. Joint mechanical strength was measured using the T-peel tests to find the preferred joining parameters for $0.3 \mathrm{~mm} \mathrm{Al}$ tabs to busbars (i.e., 1.5 bar welding pressure, $50 \mu \mathrm{m}$ welding amplitude and $0.35 \mathrm{~s}$ welding time) and $0.3 \mathrm{~mm} \mathrm{Cu}[\mathrm{Ni}]$ tabs to busbars (i.e., 1.5 bar welding pressure, $50 \mu \mathrm{m}$ welding amplitude and $0.55 \mathrm{~s}$ welding time). These UMW process parameters were used to produce samples for electrical and thermal characterisation. This paper significantly explores the following areas: 
- Electrical resistance change was decreasing with the increasing thickness of busbars, and with a higher thickness of busbar, the electrical resistance change profile exhibited a plateau. It was observed that equivalent resistance changes were obtained from the $0.3 \mathrm{~mm} \mathrm{Al} / \mathrm{Cu}[\mathrm{Ni}]$ tab to $1.5 \mathrm{~mm} \mathrm{Al} \mathrm{busbar}$ and $1.0 \mathrm{~mm} \mathrm{Cu}$ busbar.

- The electrical resistance at the start of the current application and the rate of change of electrical resistance provide additional information on the possible interchangeability of busbar materials. For example, in the case of $0.3 \mathrm{~mm} \mathrm{Cu}[\mathrm{Ni}]$ tab-to-busbar connections, equivalent electrical resistance was obtained from $1.0 \mathrm{Cu}$ and $1.5 \mathrm{~mm} \mathrm{Al} \mathrm{busbars,} 1.5 \mathrm{~mm} \mathrm{Cu}$ and $2.0 \mathrm{~mm}$ Al busbars or $2.0 \mathrm{~mm} \mathrm{Cu}$ and $2.5 \mathrm{~mm} \mathrm{Al} \mathrm{busbars.}$

- The temperature rise profiles showed that with an increase in busbar thickness, the maximum temperature measured at the joint was reduced. The average temperature increase from the $0.3 \mathrm{~mm} \mathrm{Al} \mathrm{tab}$ was 0.6 times higher than the $0.3 \mathrm{~mm} \mathrm{Al} \mathrm{tab}$, irrespective of busbar selection.

This paper provides guidelines for suitable busbar selection using UMW to facilitate better battery pack manufacturing. Furthermore, these results can be used for modelling and simulation to evaluate whole module performance.

Author Contributions: Conceptualisation, A.D.; Formal analysis, A.D. and A.B.; Funding acquisition, D.W.; Investigation, A.B.; Methodology, A.D.; Project administration, D.W.; Supervision, Iain Masters; Validation, A.B.; Writing - original draft, A.D.; Writing - review \& editing, I.M.

Funding: This research has been partially supported by WMG Centre High Value Manufacturing (HVM) Catapult and Research Development Fund from The University of Warwick, UK.

Conflicts of Interest: The authors declare no conflict of interest.

\section{References}

1. Faria, R.; Moura, P.; Delgado, J.; de Almeida, A.T. A Sustainability Assessment of Electric Vehicles as a Personal Mobility System. Energy Convers. Manag. 2012, 61, 19-30. [CrossRef]

2. Das, A.; Li, D.; Williams, D.; Greenwood, D. Joining Technologies for Automotive Battery Systems Manufacturing. World Electr. Veh. J. 2018, 9, 22. [CrossRef]

3. Union, E. Regulation (Eu) No 333/2014 of the European Parliament and of the Council of 11 March 2014 Amending Regulation (Ec) No 443/2009 to Define the Modalities for Reaching the 2020 Target to Reduce Co 2 Emissions from New Passenger Cars. Off. J. Eur. Union. 2014, 103, 15-21.

4. Union, E. Comparative Study on the Differences between the EU and US Legislation on Emissions in the Automotive Sector; Institute for European Environmental Policy: London, UK, 2016.

5. Thackeray, M.M.; Wolverton, C.; Isaacs, E.D. Electrical Energy Storage for Transportation-Approaching the Limits of, and Going Beyond, Lithium-Ion Batteries. Energy Environ. Sci. 2012, 5, 7854-7863. [CrossRef]

6. Das, A.; Li, D.; Williams, D.; Greenwood, D. Weldability and Shear Strength Feasibility Study for Automotive Electric Vehicle Battery Tab Interconnects. J. Braz. Soc. Mech. Sci. Eng. 2019, 41, 54. [CrossRef]

7. Lee, S.S.; Kim, T.H.; Hu, S.J.; Cai, W.W.; Abell, J.A. Joining Technologies for Automotive Lithium-Ion Battery Manufacturing: A Review. In Proceedings of the ASME 2010 International Manufacturing Science and Engineering Conference, Erie, PA, USA, 12-15 October 2010.

8. Kirkpatrick, L. Aluminum Electrical Conductor Handbook; The Aluminum Association: Arlington, VA, USA, 1989.

9. Pryor, L.; Schlobohm, R.; Brownell, B. A Comparison of Aluminum vs. Copper as Used in Electrical Equipment; GE Industrial Solutions: Plainville, CT, USA, 2008.

10. Fuhrmann, T.; Schlegel, S.; Grossmann, S.; Hoidis, M. Comparison between Nickel and Silver as Coating Materials of Conductors Made of Copper or Aluminum Used in Electric Power Engineering. In Proceedings of the 27th International Conference on Electrical Contacts, Dresden, Germany, 22-26 June 2014.

11. Flood, G. Ultrasonic Energy Welds Copper to Aluminium. Weld. J. 1997, 76, 43-45.

12. Lewchalermwong, N.; Masomtob, M.; Lailuck, V.; Charoenphonphanich, C. Material Selection and Assembly Method of Battery Pack for Compact Electric Vehicle. In IOP Conference Series: Materials Science and Engineering; IOP Publishing Ltd.: Bristol, UK, 2018; Volume 297, p. 012019. 
13. Das, A.; Masters, I.; Williams, D. Process robustness and strength analysis of multi-layered dissimilar joints using ultrasonic metal welding. Int. J. Adv. Manuf. Technol. 2018, 101, 881-900. [CrossRef]

14. Design Possibilities for the Chevy Bolt 2015. Available online: http://gm-volt.com/2015/06/19/designpossibilities-for-the-chevy-bolt/ (accessed on 5 July 2017).

15. Gunduz, I.E.; Ando, T.; Shattuck, E.; Wong, P.Y.; Doumanidis, C.C. Enhanced Diffusion and Phase Transformations During Ultrasonic Welding of Zinc and Aluminum. Scr. Mater. 2005, 52, 939-943. [CrossRef]

16. Ambekar, T.H.S. Additional Studies on Interface Temperatures and Bonding Mechanisms of Ultrasonic Welds. Weld. J. 1970, 49, 196-200.

17. Janaki Ram, G.D.; Yang, Y.; Stucker, B.E. Effect of Process Parameters on Bond Formation during Ultrasonic Consolidation of Aluminum Alloy 3003. J. Manuf. Syst. 2006, 25, 221-238. [CrossRef]

18. Harthoorn, J. Ultrasonic Metal Welding; Technische Hogeschool Eindhoven: Eindhoven, The Netherlands, 1978.

19. Patel, V.K.; Bhole, S.D.; Chen, D.L. Microstructure and Mechanical Properties of Dissimilar Welded Mg-Al Joints by Ultrasonic Spot Welding Technique. Sci. Technol. Weld. Join. 2012, 17, 202-206. [CrossRef]

20. Shawn Lee, S.; Hyung Kim, T.; Jack Hu, S.; Cai, W.W.; Abell, J.A.; Li, J. Characterization of Joint Quality in Ultrasonic Welding of Battery Tabs. J. Manuf. Sci. Eng. 2013, 135, 021004. [CrossRef]

21. Shakil, M.; Tariq, N.H.; Ahmad, M.; Choudhary, M.A.; Akhter, J.I.; Babu, S.S. Effect of Ultrasonic Welding Parameters on Microstructure and Mechanical Properties of Dissimilar Joints. Mater. Des. 2014, 55, $263-273$. [CrossRef]

22. Lee, D.; Kannatey-Asibu, E.; Cai, W. Ultrasonic Welding Simulations for Multiple Layers of Lithium-Ion Battery Tabs. J. Manuf. Sci. Eng. 2013, 135, 061011. [CrossRef]

23. Elangovan, S.; Prakasan, K.; Jaiganesh, V. Optimization of Ultrasonic Welding Parameters for Copper to Copper Joints Using Design of Experiments. Int. J. Adv. Manuf. Technol. 2010, 51, 163-171. [CrossRef]

24. Kim, T.H.; Yum, J.; Hu, S.J.; Spicer, J.P.; Abell, J.A. Process Robustness of Single Lap Ultrasonic Welding of Thin, Dissimilar Materials. CIRP Ann. Manuf. Technol. 2011, 60, 17-20. [CrossRef]

25. Kang, B.; Cai, W.; Tan, C.A. Vibrational Energy Loss Analysis in Battery Tab Ultrasonic Welding. J. Manuf. Processes 2014, 16, 218-232. [CrossRef]

26. Kang, B.; Cai, W.; Tan, C.A. Dynamic Response of Battery Tabs under Ultrasonic Welding. J. Manuf. Sci. Eng. 2013, 135, 051013. [CrossRef]

27. Khayam, U.; Hadisoeseno, N.P.Y.; Risdiyanto, A. Reducing Contact Resistance of High Current Connectors on Electric Vehicle by Controlling Contact Pressure and Addition of Plating Material. In Proceedings of the 2017 4th International Conference on Electric Vehicular Technology (ICEVT), Bali, Indonesia, 2-5 October 2017.

28. Gatherer, J. A Study of the Effect of Various Material Combinations on the Bolted Contacts of Busbars. Master's Thesis, Auburn University, Oban, AL, USA, 2013.

29. Brand, M.J.; Schmidt, P.A.; Zaeh, M.F.; Jossen, A. Welding techniques for battery cells and resulting electrical contact resistances. J. Energy Storage 2015, 1, 7-14. [CrossRef]

30. Das, A.; Ashwin, T.R.; Barai, A. Modelling and Characterisation of Ultrasonic Joints for Li-Ion Batteries to Evaluate the Impact on Electrical Resistance and Temperature Raise. J. Energy Storage 2019, 22, 239-248. [CrossRef]

31. JMBS. Our Guide to Batteries; Johnson Matthey Battery Systems: Milton Keynes, UK, 2015.

32. Chapman, D.; Norris, T. Copper for Busbars: Guidance for Design and Installation; Copper Development Association: Hertfordshire, UK, 2014.

33. Hosseinzadeh, E.; Genieser, R.; Worwood, D.; Barai, A.; Marco, J.; Jennings, P. A Systematic Approach for Electrochemical-Thermal Modelling of a Large Format Lithium-Ion Battery for Electric Vehicle Application. J. Power Sources 2018, 382, 77-94. [CrossRef]

34. Worwood, D.; Hosseinzadeh, E.; Kellner, Q.; Marco, J.; Greenwood, D.; Mcglen, R.; Widanage, W.D.; Barai, A.; Jennings, P. Thermal Analysis of a Lithium-Ion Pouch Cell under Aggressive Automotive Duty Cycles with Minimal Cooling. In Proceedings of the 6th Hybrid and Electric Vehicles Conference (HEVC 2016), London, UK, 2-3 November 2016.

35. Rossiter, P.L. The Electrical Resistivity of Metals and Alloys; Cambridge University Press: Cambridge, UK, 1991. 
36. Waldmann, T.; Wilka, M.; Kasper, M.; Fleischhammer, M.; Wohlfahrt-Mehrens, M. Temperature Dependent Ageing Mechanisms in Lithium-Ion Batteries_A Post-Mortem Study. J. Power Sources 2014, 262, 129-135. [CrossRef]

37. Hunt, I.A.; Zhao, Y.; Patel, Y.; Offer, G. Surface Cooling Causes Accelerated Degradation Compared to Tab Cooling for Lithium-Ion Pouch Cells. J. Electrochem. Soc. 2016, 163, A1846-A1852. [CrossRef] 